Karstenia 56: 13-26

\title{
Inocybe baltica and I. suecica, two new smooth- spored species from the Baltic Sea region
}

\author{
JUKKA VAURAS and ELLEN LARSSON
}

\begin{abstract}
VAURAS, J. \& LARSSON, E. 2016: Inocybe baltica and I. suecica, two new smoothspored species from the Baltic Sea region. - Karstenia 56: 13-26. HELSINKI. ISSN 0453-3402.
\end{abstract}

\begin{abstract}
Two new species, with pruinose stipe and smooth spores, are described from Fennoscandia and Estonia. Inocybe baltica is a rather large species, associated with Pinus sylvestris on calcareous sandy soils, often occurring at seashores. I. suecica is a smaller species associated with deciduous trees on more rich and calcareous soils, often found in parks and cemeteries. Both species are so far known to occur only in the hemiboreal zone.
\end{abstract}

Key words: Inocybe, Agaricales, taxonomy, molecular systematics, hemiboreal zone, Europe

Jukka Vauras, Biological Collections of Åbo Akademi University, Herbarium, FI-20014 University of Turku, Finland; e-mail: jukvau@utu.fi

Ellen Larsson, University of Gothenburg, Department of Biological and Environmental Sciences, Box 461, SE-40530 Göteborg, Sweden; e-mail: ellen.larsson@bioenv.gu.se

\section{Introduction}

The genus Inocybe (Fr.) Fr. must be considered more extensively studied in Europe than in other areas of the world, and based on morphology more than 200 species have been described and classified (e.g. Boursier \& Kühner 1926, Kühner 1933, 1955a, 1955b, Favre 1955, Alessio \& Rebaudengo 1980, Kuyper 1986, Kühner 1988, Stangl 1989, Ferrari 2006, 2010, Ferrari et al. 2014). Even so, by comparison and analyses of molecular sequence data, particularly from the ITS region, new undescribed species are continuously identified. By using an integrative approach, several new species including their phylogenetic position have recently been described (e.g. Vauras \& Kokkonen 2009, Vauras \& Larsson 2011, Kokkonen \& Vauras 2012, Jacobsson \& Larsson 2015, Esteve-Raventos et al. 2015, 2016, Vauras \& Larsson 2016).
The species of Inocybe that are characterized by having mostly thick-walled pleurocystidia, are in the traditional classifications placed in subgenus Inocybe. The subgenus is divided into two supersections, Cortinatae Kühner \& Boursier and Marginatae Kühner. Species in Cortinatae have a cortina at young states, and a stipe that is slightly pruinose at stipe apex only or not at all. Species in Marginatae lack cortina and have a stipe that is pruinose all over or nearly so (Stangl 1989). The smooth-spored species of Marginatae are traditionally classified to form the section Splendentes Singer. Many of the species in this group also have a bulbous stipe base. In this article we describe and illustrate two new species, I. baltica and I. suecica, which according to the macro- and micro-morphological characters would fit as members of the Splendentes. Both species are found in the hemiboreal zone of the Baltic Region. 


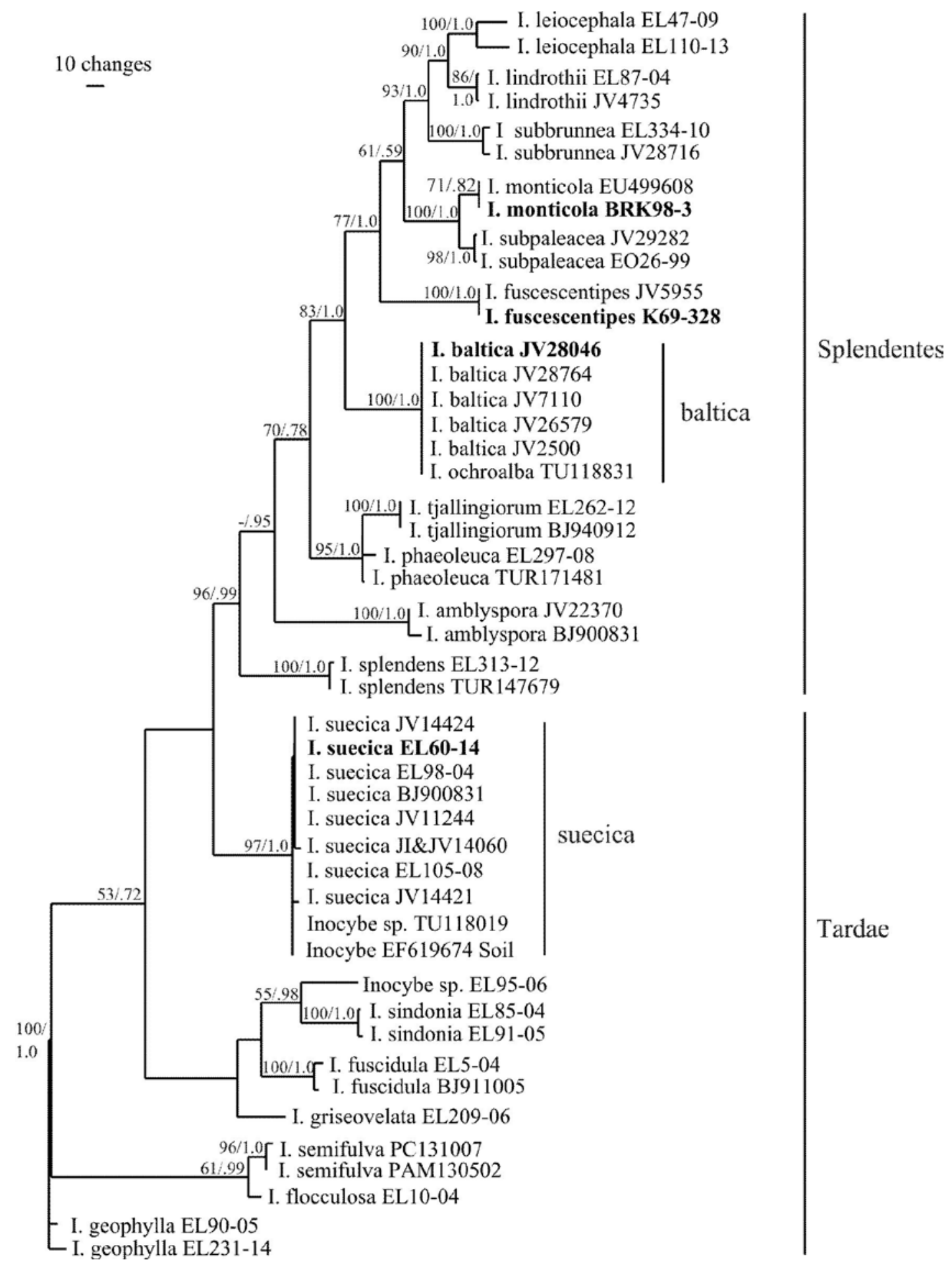




\section{Material and methods}

The main portion of the specimens were collected by the authors in northwest Europe (Fennoscandia and Estonia). Additional material was included from GB, $\mathrm{H}$ and TU. Selected collections were photographed in situ. Macroscopical features were noted and cross-sections drawn from fresh fruit bodies. The colour codes refer to Cailleux (1981) or Küppers (1981). Microscopical characters were measured and drawn from dried material mounted in $10 \%$ $\mathrm{NH}_{4} \mathrm{OH}$ solution following the methodology described in Vauras \& Kokkonen (2009).

Sequence data of eleven specimens of the two new identified species were generated for this study. Seven ITS sequences were generated through the Finnish Barcode of Life (www.finbol.org). For the residual, sequences from the complete ITS region and 1400 base pairs (bp) of the 5'end of the LSU nuclear ribosomal DNA were generated. DNA extractions, PCR reactions, and sequencing were performed as described in Larsson \& Örstadius (2008). Primers used to amplify the complete ITS region and the 5 'end of the LSU region were ITS1F (Gardes \& Bruns 1993) and LR21, LR0R, and LR7 (Hopple \& Vilgalys 1999). Primers used for sequencing were ITS1, ITS4 (White et al. 1990), Ctb6 (http://plantbio.berkeley. edu/ bruns/) and Lr5 (Hopple \& Vilgalys 1999). Sequences were edited and assembled using Sequencher 5.1 (Gene Codes, Ann Arbor, Michigan). Sequences generated for this study have been deposited in GenBank and accession numbers given (KX384172-KX384182).

In addition, sequence data of two specimens already published (Larsson et al. 2014), and three sequences identified though blast searches in GenBank and UNITE (Kõljalg et al. 2013) belonging to the new species were identified and included. The sequenced specimens are indicated with an asterisk in lists of specimens examined.

To place the new species in a phylogenetic context ITS and LSU sequence data from previous studies on Inocybe were selected (Ryberg et al. 2010, Larsson et al. 2014).

Fig. 1. One of the most parsimonious trees from the parsimony analysis based on ITS and LSU sequence data, presented as a phylogram and showing the phylogenetic position of Inocybe baltica and I. suecica. Scale bars indicate limits of sections Splendentes and Tardae. Parsimony bootstrap values and Bayesian Posterior Probabilities are indicated on branches. Sequences originating from type specimens are marked in bold. Abbreviations of collectors or herbarium numbers: EL = Ellen Larsson, $\mathrm{JV}=$ Jukka Vauras, BJ $=$ Bo Jansson, BRK $=$ Bradley R. Kropp, EO = Esteri Ohenoja, JI = Jouni Issakainen, $\mathrm{K}=$ Robert Kühner, PAM = Pierre-Arthur Moreau; PC = Penny Cullington; TU and TUR are Herbarium acronyms.
Alignment was performed using the L-INS-i strategy as implemented in MAFFT v. 7.017 (Katoh \& Standley 2013). The alignment was adjusted manually using the data editor in PAUP* 4.0b12 (Swofford 2003). For inferring phylogenetic relationships among species heuristic searches for the most parsimonious trees were performed using PAUP* (Swofford 2003). All transformations were considered unordered and equally weighted. Variable regions with ambiguous alignment were excluded and gaps were treated as missing data. Heuristic searches with 1,000 random-addition sequence replicates and TBR branch swapping were performed, saving at most 25 trees in each replicate. Relative robustness of clades was assessed by the bootstrap method using 1,000 heuristic search replicates with 10 random taxon addition sequence replicates and TBR branch swapping, the latter saving at most 25 trees in each replicate. A Bayesian analysis was carried out in MrBayes 3.0 (Ronquist \& Huelsenbeck 2003), with a best-fit model of nucleotide evolution supplied by MrModeltest 2.2 (Nylander 2004). Eight default-setting Metropolis-Coupled Markov Chain Monte Carlo (MCMCMC) chains were run for 10 million generations with trees sampled every 5,000 generations and an initial burn-in of 1000 trees. After discarding the trees prior to the burn-in threshold a $50 \%$ majority-rule consensus phylogram was computed from the remaining trees. As suggested by MrModeltest, the nucleotide evolution model $\mathrm{HKY}+\mathrm{G}$ was used for the ITS1 spacer; $\mathrm{K} 80$ was used for the $5.8 \mathrm{~S}$ gene; $\mathrm{HKY}+\mathrm{I}+\mathrm{G}$ was used for the ITS2 spacer and the LSU in the Bayesian analysis. The MCMC analysis converged well in advance of the burn-in threshold and chain mixing was found to be satisfactory, as assessed by using Tracer v1.5 (Drummond et al. 2012)

The aligned complete dataset consisted of 47 sequences and 2198 characters. After exclusion of ambiguous regions mainly from the ITS region and the beginning and end of the data set, 1886 characters remained for the analysis. Of these, 1519 were constant, 52 were variable but parsimony uninformative, and $315(17 \%)$ were parsimony informative. The maximum parsimony analysis yielded 24125 equally most parsimonious trees (length $=837$ steps, $\mathrm{CI}=0.5880$, and $\mathrm{RI}=0.8298$ ). One of the trees is presented as a phylogram in Fig. 1. The bootstrap analysis recovered the clade including the six sequences of $I$. baltica $(100 \%$ BS) nested among species in section Splendentes, super-section Marginatae with strong support. The clade with ten sequences of I. suecica $(97 \% \mathrm{BS})$ came out on a single branch among species belonging to section Tardae and super-section Cortinatae, Fig 1. The Bayesian tree topology was basically identical to the MP bootstrap tree. In the analysis the two clades were also recovered as monophyletic and with strong support. The recovered Bayesian posterior probability (BPP) values are indicated on branches in Fig. 1. 
Inocybe baltica Vauras \& E. Larss., sp. nova - Figs. 2-5, 9

MycoBank no.: MB819179

Diagnosis: Rather large and stout species with brown pileus, totally pruinose, bulbose stipe which is first white, then reddish to yellowbrownish, smell indistinct, spores smooth and fairly small, measuring (6.9-)7.2-9.5(-10.3) $\times$ (4.4-)4.5-5.6(-5.7) $\mu \mathrm{m}$, pleurocystidia rather small, measuring $(38-) 40-58(-63) \times 11-18(-21)$ $\mu \mathrm{m}$. Habitat on sandy, calcareous soil, associated with Pinus sylvestris.

Typus: Estonia. Hiiumaa. Kõrgessaare, Kõpu cape, Kaleste, near the camping place, Forest with Pinus sylvestris near seashore, on fine sandy soil by path, alt. ca. $5 \mathrm{~m}$., ca $58^{\circ} 54^{\prime} 35^{\prime \prime} \mathrm{N}$, $22^{\circ} 08^{\prime} 10^{\prime \prime}$ E, 23.IX.2010 Vauras $28046 F$ (TURA - holotype; AH, GB, H, KR, TU - isotypes, GenBank no. KX384172).

Etymology: baltica, growing on coasts of theBaltic Sea.

Pileus $1.8-7.5 \mathrm{~cm}$ in diam, conico-convex, convex to applanate, without or with broad, low umbo, margin when young deflexed to inflexed, later straight to reflexed, when young pale brown $(60 \mathrm{P}, 47 \mathrm{~N}, 47 \mathrm{P}, 49 \mathrm{M}, 49 \mathrm{~N}, 49 \mathrm{P}, 70 \mathrm{C})$ to greyish brown, centre brown, cream $(69 \mathrm{M}, 71 \mathrm{M})$ to blackish brown (70T); then brown (49P, 49R, 69N, 67P), yellow-brown, dark-brown (69S), smooth around centre, towards margin fibrillosetomentose, partly subsquamulose, often with darker brown fibrils, silky shiny, margin rarely breaking up; when young often with silverywhite velipellis. Lamellae moderately crowded, up to $8 \mathrm{~mm}$ wide, subventricose, narrowly adnate to free, first whitish to creamy-white, then pale grey (Y30M20C20), pale brownish grey, pale grey-brown (S20Y50M20, 70M), pale brown to brown, edge concolorous to pale. Stipe 2.0-6.3 $\times 0.35-1.5 \mathrm{~cm}$, equal to slightly clavate, sometimes widest at apex, base often bulbous, but not marginately bulbous, up to $1.4 \mathrm{~cm}$ wide; when young white, pale reddish, pale yellowish, pale brownish yellow, often white at apex and base, later pale brown, near base often somewhat black, more abundantly when old, whitepruinose to the base, longitudinally striate, silky shiny. Cortina not present. Context in pileus whitish, pale brownish under cuticle, in stipe slightly reddish to pale brown, whitish at base and apex, shiny. Smell indistinct. Spores (6.97.2-8.2-9.5(-10.3) × (4.4-) 4.5-5.1-5.6(-5.7) $\mu \mathrm{m}$, range of mean values $7.8-8.8 \times 4.8-5.3 \mu \mathrm{m}$, $\mathrm{Q}=(1.4-) 1.45-1.63-1.85(-1.9)$, range of mean Q -values 1.56-1.77 (140 spores from 7 collections); smooth, subamygdaliform, mostly with obtuse apex, some with indistinctly subconical apex, yellow brown. Basidia 22-27-33 × 7-8-9 $\mu \mathrm{m}$, clavate, 4 -spored (30 basidia from 3 collections). Pleurocystidia (38-)40-48-58(-63) $\times 11-14-18(-21) \mu \mathrm{m}$ (71 pleurocystidia from 7 collections), subfusiform to subutriform, often with a pedicel, thick-walled, with up to $4 \mu \mathrm{m}$ thick, colourless to pale yellow wall, mostly with scarce to abundant crystals; frequent. Cheilocystidia somewhat similar to pleurocystidia but wider, more variable and partly with rounded base, some with yellow-brown contents, (28) $34-40-47(-53) \times(12-) 13-17-20(-21) \mu \mathrm{m}(\mathrm{n}=$ 27); paracystidia moderately scarce, pyriform to clavate, $(12-) 14-18-22(-25) \times(6-) 7-8-12 \mu \mathrm{m}$ $(\mathrm{n}=20)$. Caulocystidia descending to base of stipe, at apex (27-)30-41-50(-56) × 11-14-18 $\mu \mathrm{m}(\mathrm{n}=22)$, more variable than pleurocystidia; cauloparacystidia at stipe apex mostly clavate or pyriform, 18-23-29 × 9-12-29 $\mu \mathrm{m}(\mathrm{n}=15)$.

\section{Other specimens examined: ESTONIA.Harju-} maa. Kuusalu, Juminda cape, Lahemaa National Park, 19.IX.2009 Vauras 27220F (TUR-A, GB). Hiiumaa. Emmaste, S of Jõesuu, 25.IX.2010 Vauras 27890 (TUR-A); Kõrgessaare, Kõpu cape, Kaleste, near the camping place, 23.IX.2010 Vauras 28044 (TUR-A). Saaremaa. Kaarma, Mändjala, near the hotel, 19.IX.2008 Vauras 26579F* (TUR-A, GB); Järve Dunes Landscape Reserve, 12.X.2013 Liiv* (TU); Kihelkonna, Odalätsi, 19.IX.2008 Vauras 26591 (TUR-A). FINLAND. Varsinais-Suomi. Lohja, Virkkala, Kyrkstad, 1.IX.1986 Vauras 2377 (TUR-A), 17.IX.1986 Vauras 2500F* (TURA), 1.IX.1987 Vauras 2901 (TUR-A); Parainen, Storgård, Malmnäs. 2.IX.1992 Vauras $7110 F^{*}$ (TUR-A, GB), 31.VIII2016 Toivonen \& Vauras 31700F, 31701, 31702 (TUR-A). SWEDEN. Gotland. Ardre, Ljugarn, 30.IX.2011 Vauras $28764 F^{*}$ (TUR-A, GB). 


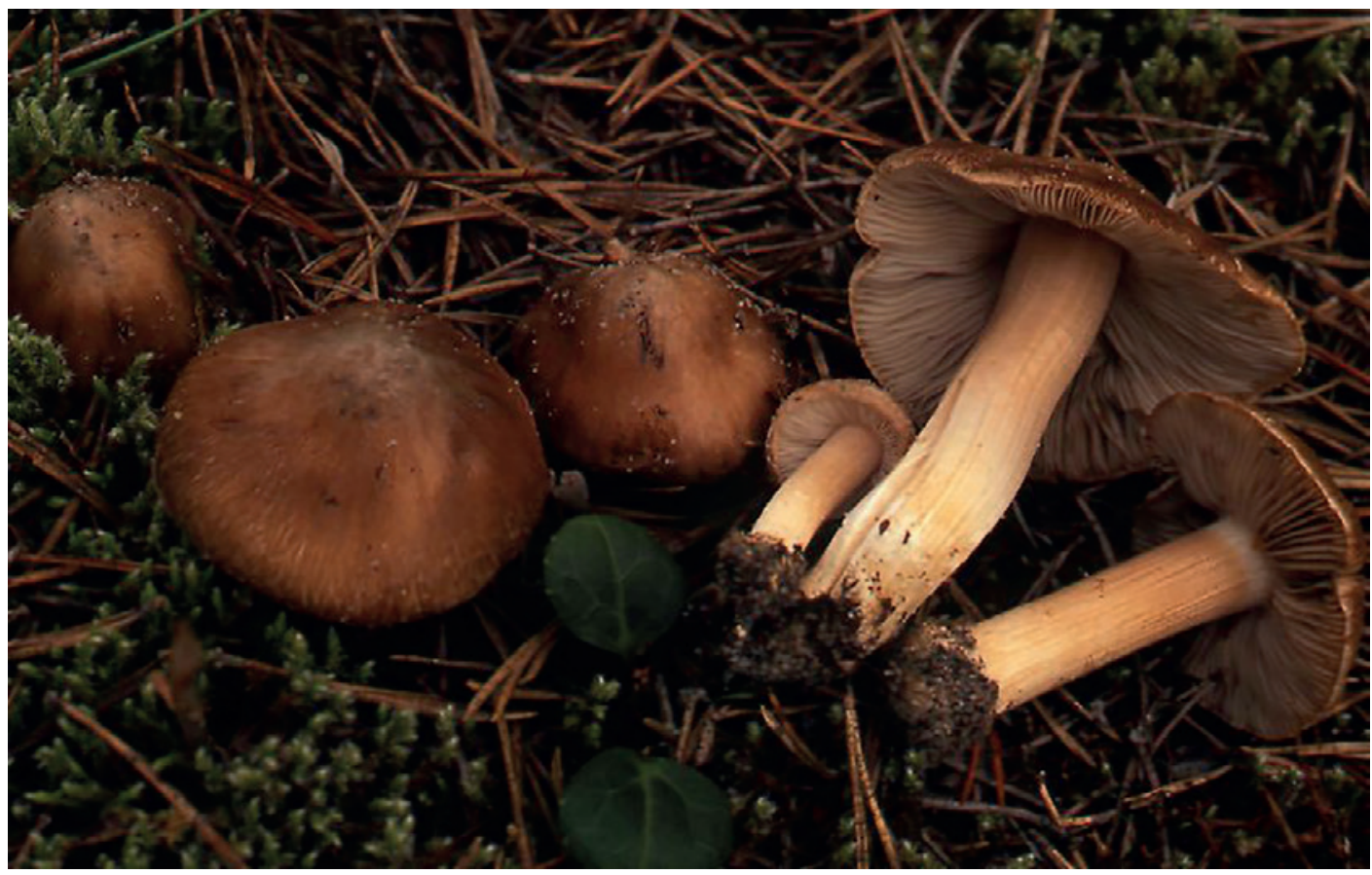

Fig. 2. Inocybe baltica. Fruiting bodies on sandy seashore in Mändjala, Saaremaa, Estonia. Vauras $26579 F$. - Photo: J. Vauras.

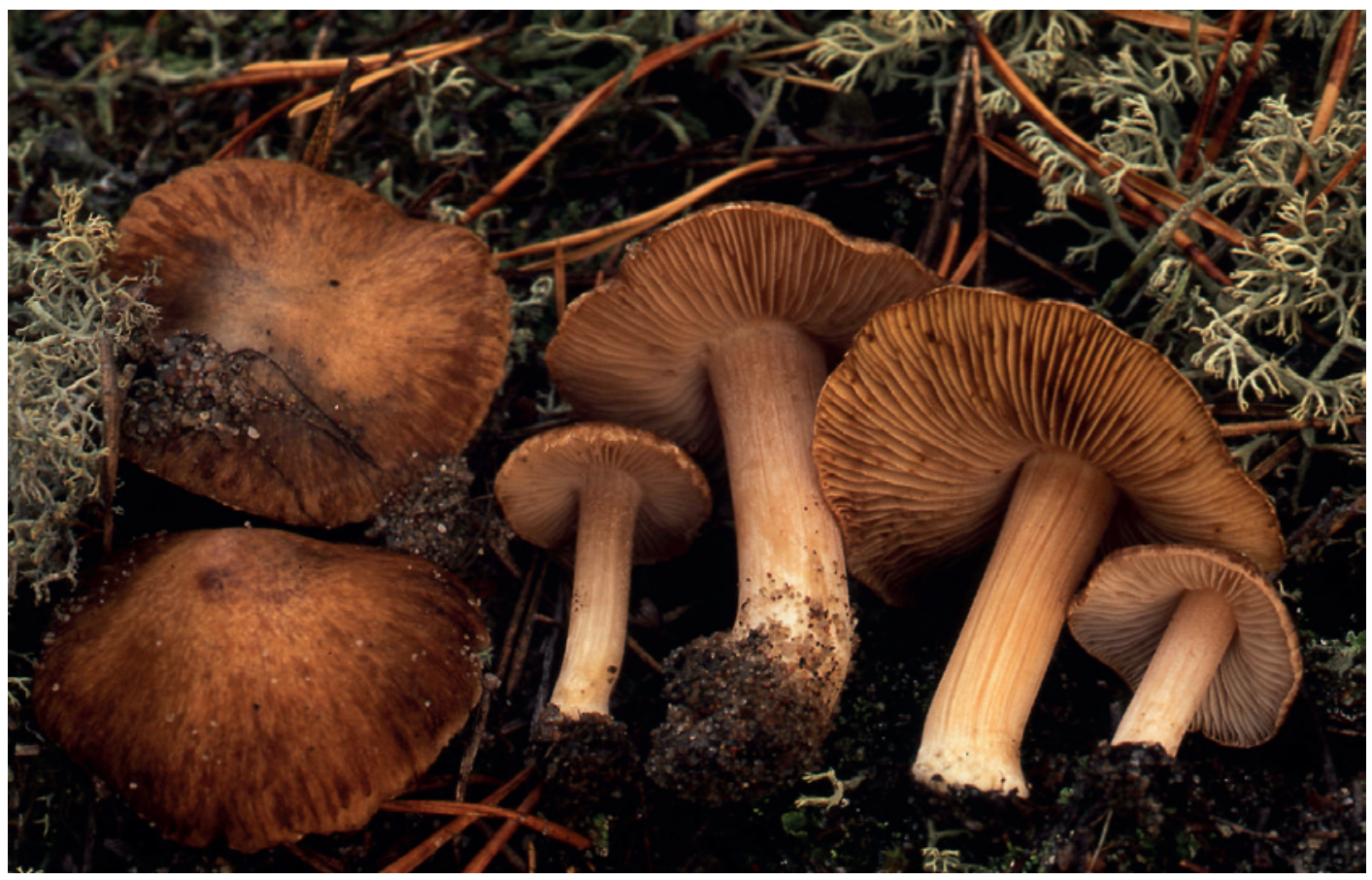

Fig. 3. Inocybe baltica, holotype. - Photo: J. Vauras. 


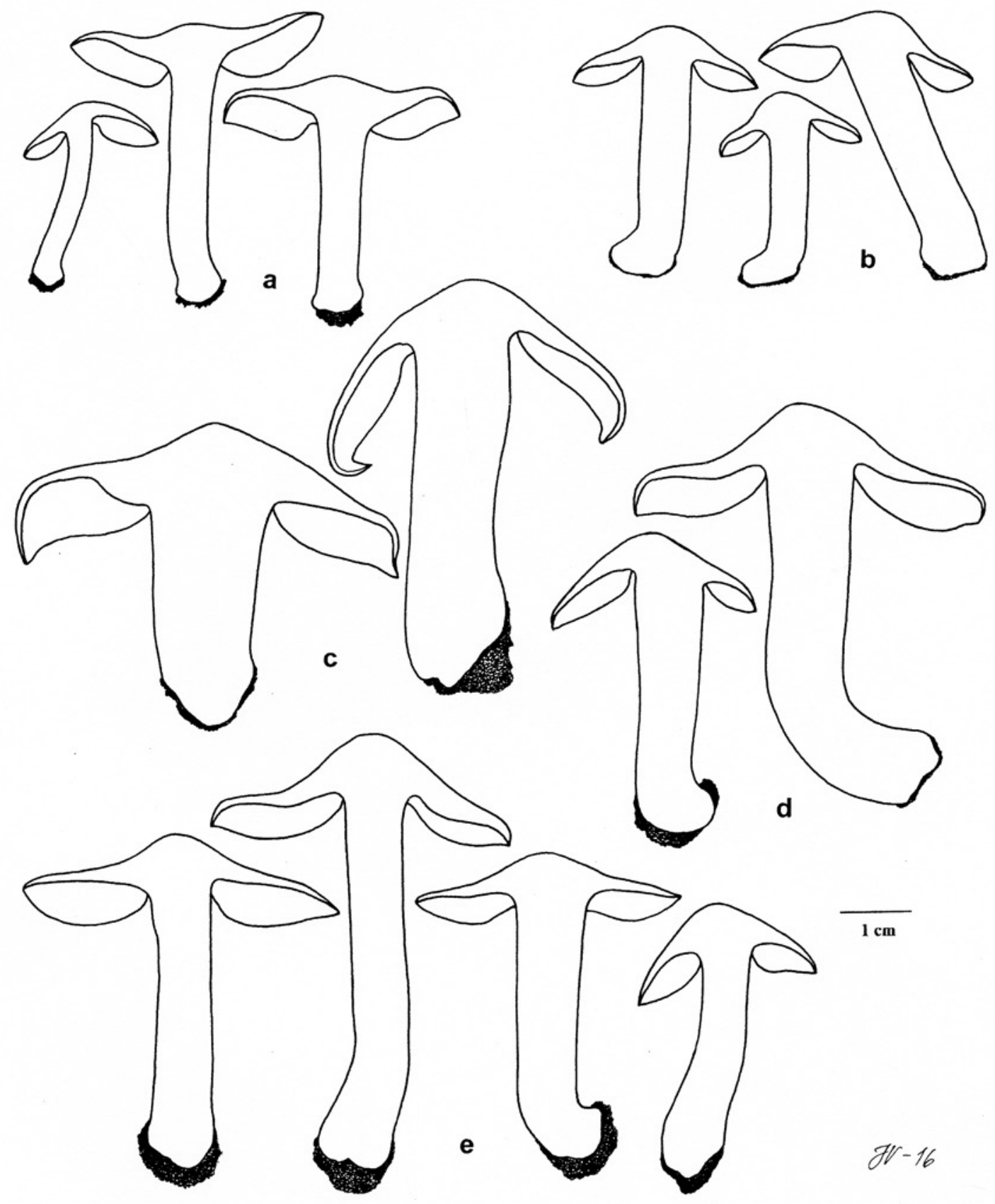

Fig. 4. Cross-sections of fruiting bodies of Inocybe baltica. - a) From Vauras 2500F, b) from Vauras 27220F, c) from Vauras $28764 F$, d) from Vauras $26579 F$, e) from holotype. 

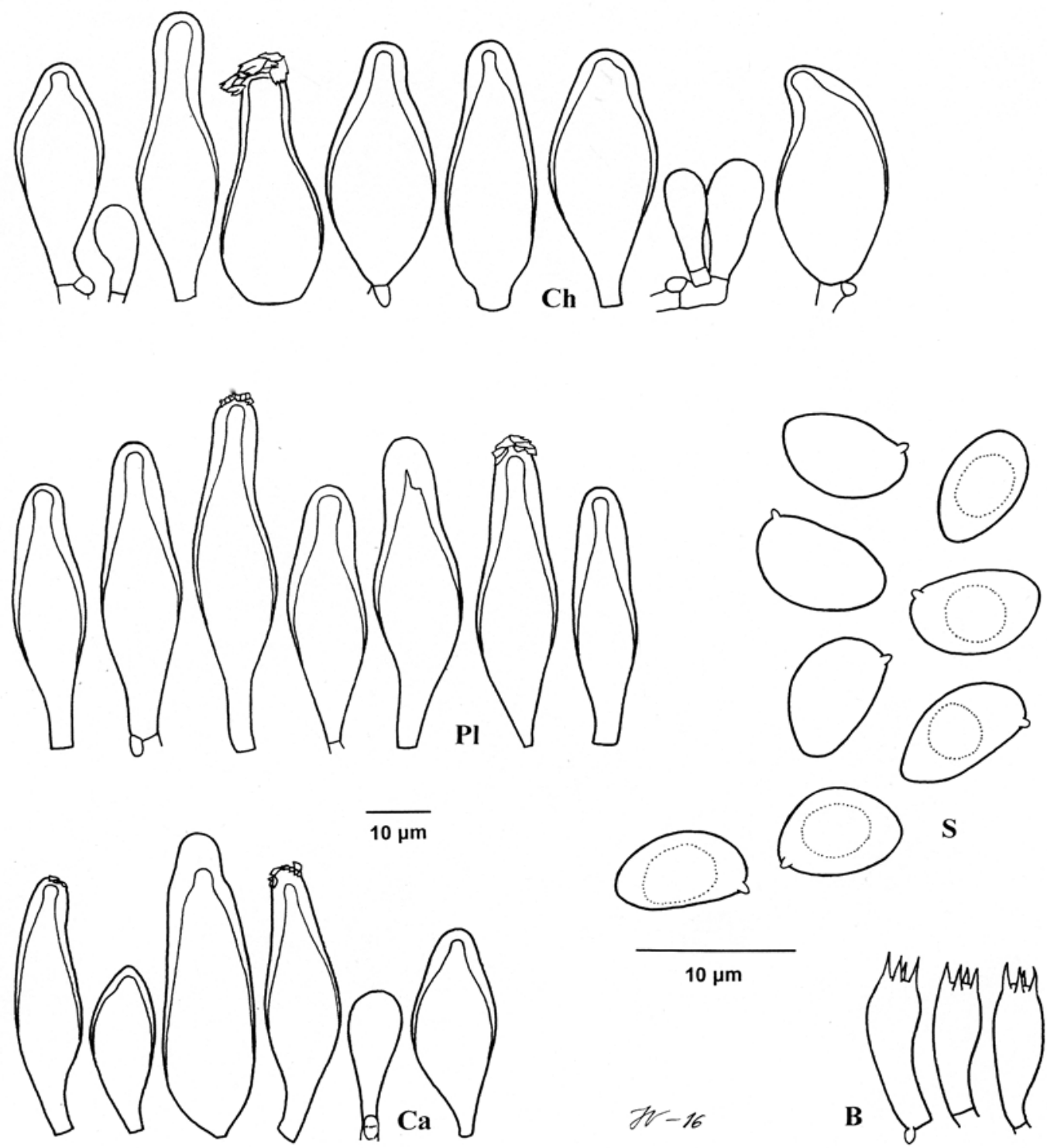

Fig. 5. Microscopical characters of Inocybe baltica (holotype). $\mathrm{B}=$ basidia, $\mathrm{Ca}=$ caulocystidia and paracystidia at stipe apex, $\mathrm{Ch}=$ cheilocystidia and paracystidia, $\mathrm{Pl}=$ pleurocystidia, $\mathrm{S}=$ spores. 
Inocybe baltica seems to be associated with and likely forming ectomycorrhiza with Pinus sylvestris. All collections have been found on calcareous sandy soils. The species has been encountered on sandy seashores and inland dunes at margins of pine forests. The Finnish localities are in vicinity of limestone plants, from which chalk dust was earlier emitted abundantly to environment. Other fungi observed close to $I$. baltica include Helvella crispa (Scop.) Fr., Inocybe inodora Velen., I. leucoblema Kühner, I. pargasensis Vauras, I. terrigena (Fr.) Kühner, I. umbrinella Bres., Russula depallens (Pers. : Fr.) Fr., R. torulosa Bres., Tricholoma albobrunneum (Pers.: Fr.) P. Kumm. and T. terreum (Schaeff.) P. Kumm.

Inocybe baltica has a distribution in the hemiboreal zone of Estonia, Finland and Sweden, and most collections have been found on the larger islands and coast areas of the Baltic Sea (Fig. 9), suggesting strong affinity to calcareous ground. Most collections are from September.

\section{Discussion}

Inocybe baltica is characterized by rather large size, brown pileus with silvery-white velipellis when young, totally pruinose, bulbous stipe and indistinct smell. Microscopically, the rather small, smooth spores and short pleurocystidia are useful in identification. Further, the species grows on sandy, calcareous soils near Pinus sylvestris in the hemiboreal zone. Macroscopically it is a typical member of the section Splendentes. This is also confirmed by the phylogenetic analyses (Fig. 1). I. amblyspora Kühner has spores and pleurocystidia rather the same size, but it's stipe base has very conspicuous marginate bulb. I. phaeoleuca Kühner, I. splendens R. Heim and I. splendentoides Bon differ by e.g. larger spores and pleurocystidia.

Inocybe suecica Vauras \& E. Larss.,
$\begin{aligned} & \text { sp. nova } \\ & \text { - Figs. 1, 6-9 }\end{aligned}$

MycoBank no.: MB819180

Diagnosis: Rather small-sized species with brown, fibrillose pileus, stipe pale to pale brown, equal to clavate, slightly bulbous, almost totally pruinose, smell spermatic, spores smooth and fairly small, measuring 7.8-9.7(-10.5) × (4.4-) 4.5-5.4(-5.7) $\mu \mathrm{m}$, pleurocystidia rather narrow, measuring (44-)49-68(-74) × (11-)12-17(-20) $\mu \mathrm{m}$. Habitat on mull, somewhat calcareous, richer soils, associated with deciduous trees.

Typus: Sweden. Västergötland. Alingsås, Nolhagaparken, under old Quercus robur, on soil amongst grasses and mosses, other trees in the area Fagus sylvatica, Tilia cordata, Betula pendula and Alnus glutinosa. Alt. ca. $60 \mathrm{~m}$. Koord.: ca. $57^{\circ} 55^{\prime} 50^{\prime \prime} \mathrm{N}, 12^{\circ} 30^{\prime} 56^{\prime \prime}$ E, 26.VIII. 2014 Larsson EL60-14 (GB - holotype; TUR-A - isotype, GenBank no. KX384177).

Etymology: the species is dedicated to the memory of our late friend Juhani Ruotsalainen (his Finnish family name means "Swedish", hence "suecica" !) The holotype specimen selected also originates from Sweden.

Pileus $0.9-2.5 \mathrm{~cm}$ in diam, when young convex to conico-convex, then expanding, with broad, obtuse umbo, darkest at centre, brown, dark brown (30T), blackish-brown (39S), reddish brown, margin brown (49P, 59N, 59P, S40Y50M30) to pale brown, at center smooth, towards margin fibrillose, margin often somewhat breaking up; rarely with some pale velipellis at centre. Lamellae moderately crowded, up to $3 \mathrm{~mm}$ wide, subventricose, narrowly adnate to free, pale grey, then pale grey-brown to pale brown, edge concolorous to pale. Stipe 1.3-3.7 $\times 0.15-0.25 \mathrm{~cm}$, equal to slightly clavate, base often slightly bulbous, up to $0.4 \mathrm{~cm}$ wide; pale, slightly reddish or brownish to yellowbrown, white-pruinose nearly to the base, longitudinally striate, indistinctly white-fibrillose at base. Cortina not present. Context in pileus whitish, in stipe whitish, partly slightly brownish to yellowish, shiny. Smell spermatic. Spores 7.8-8.6-9.7(-10.5) × (4.4-)4.5-4.9-5.4(-5.7) $\mu \mathrm{m}$, range of mean values $8.3-8.9 \times 4.8-5.0$ $\mu \mathrm{m}, \mathrm{Q}=(1.45-) 1.55-1.76-1.95(-2.05)$, range of mean Q -values 1.72-1.87 (120 spores from 6 collections); smooth, subamygdaliform, with subconical apex, pale yellow brown. Basidia 20-26-30 × 7-8-9(-10) $\mu \mathrm{m}$, clavate, 4-spored (32 basidia from 5 collections). Pleurocystidia (44-)49-57-68(-74) × (11-)12-14-17(-20) $\mu \mathrm{m}$ (103 pleurocystidia from 7 collections), sub- 


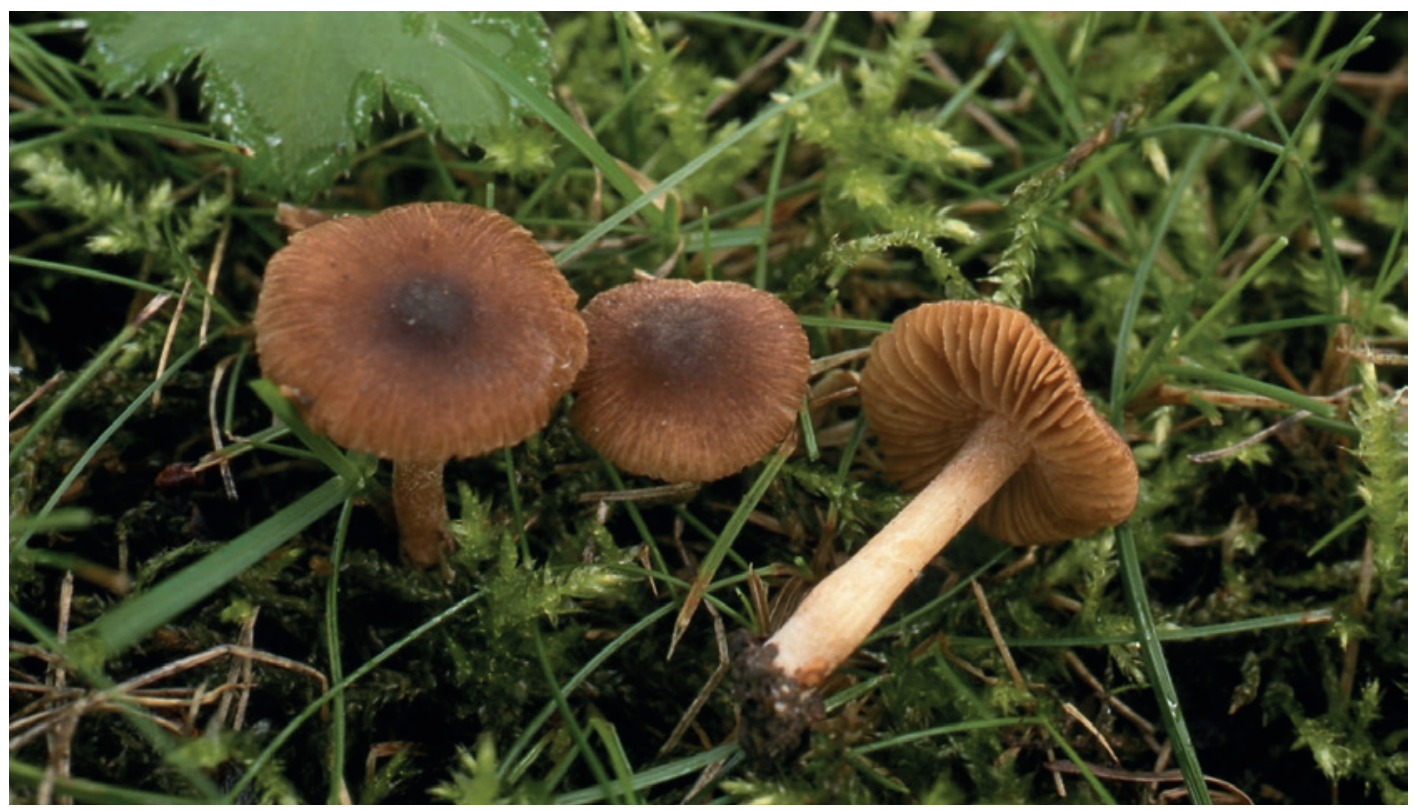

Fig. 6. Inocybe suecica. Fruiting bodies on shady lawn in Turku, Varsinais-Suomi, Finland. Issakainen \& Vauras 14060F. - Photo: J. Vauras.

fusiform to sublageniform, often with a short pedicel, thick-walled, with up to $2-3 \mu \mathrm{m}$ thick, pale yellow to yellow wall, mostly with scarce to abundant crystals; frequent. Cheilocystidia fairly similar to pleurocystidia but shorter, more variable and partly with rounded base, 38-47-59($61) \times 11-15-18(-19) \mu \mathrm{m}(\mathrm{n}=26)$; paracystidia moderately abundant, oval, pyriform to clavate, 12-20-28(-30) × 7-10-14(-15) $\mu \mathrm{m}(\mathrm{n}=32)$. Caulocystidia descending to base of stipe, at apex (29-)32-50-72(-83) × (10-)12-16-18 $\mu \mathrm{m}$ $(\mathrm{n}=31)$, more variable than pleurocystidia and cheilocystidia, often with rounded base; cauloparacystidia at stipe apex oval, rather sphaerical, clavate or pyriform, $15-23-28 \times(7-) 8-13-20(-$ 22) $\mu \mathrm{m}(\mathrm{n}=28)$.

Fig. 7. Inocybe suecica, holotype. - Photo: E. Larsson.

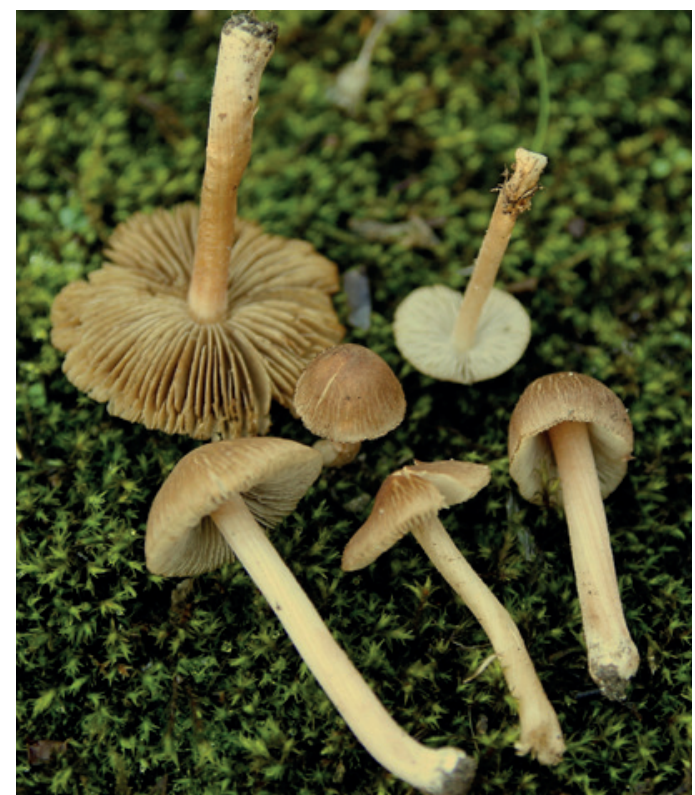



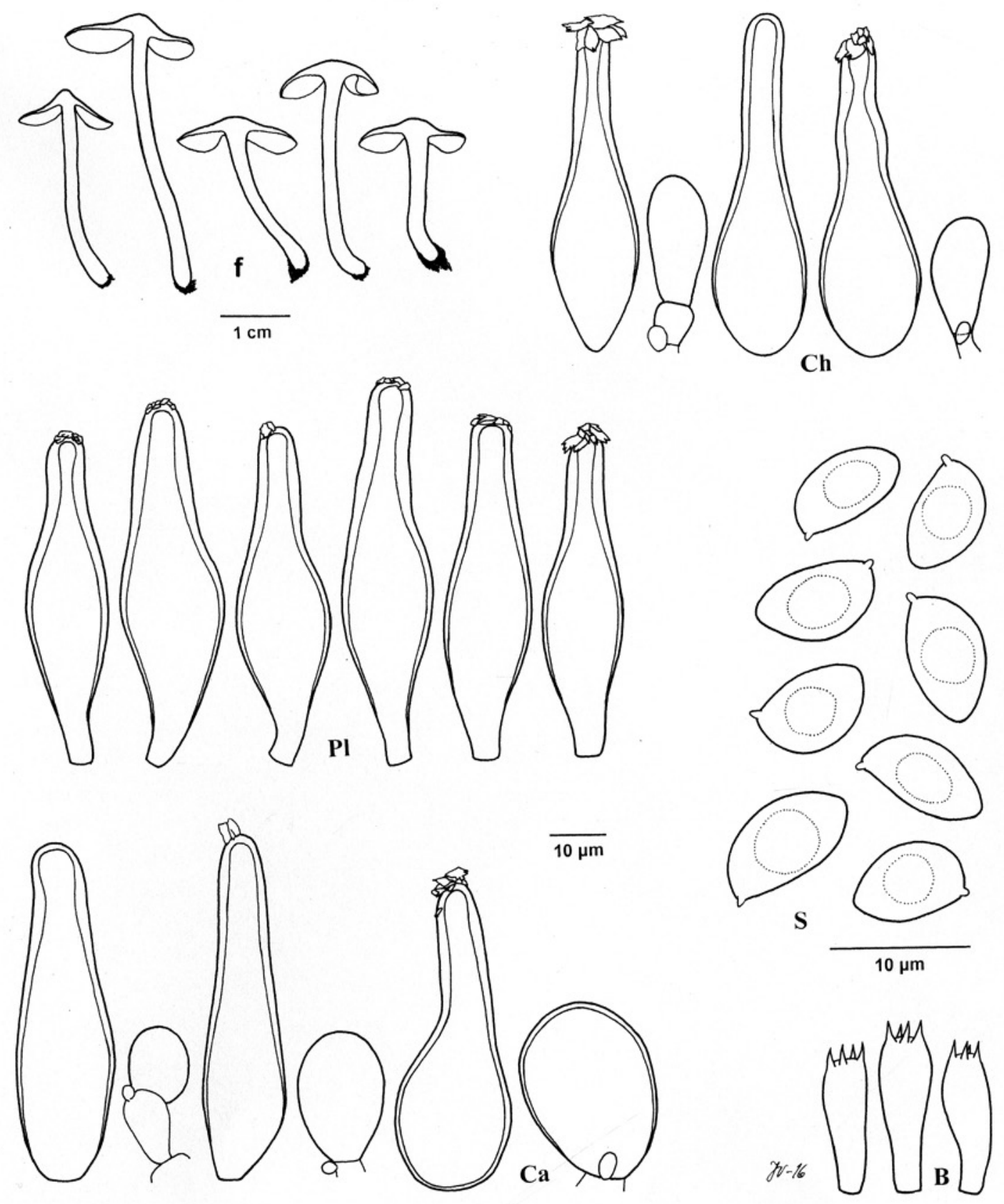

Fig. 8.Microscopical characters of Inocybe suecica (isotype) and cross-sections of fruiting bodies (f), from left, Vauras $14424 F, 14421 F, 13759 F, 11244 F, 14060 F$. For symbols, see Fig. 5. 


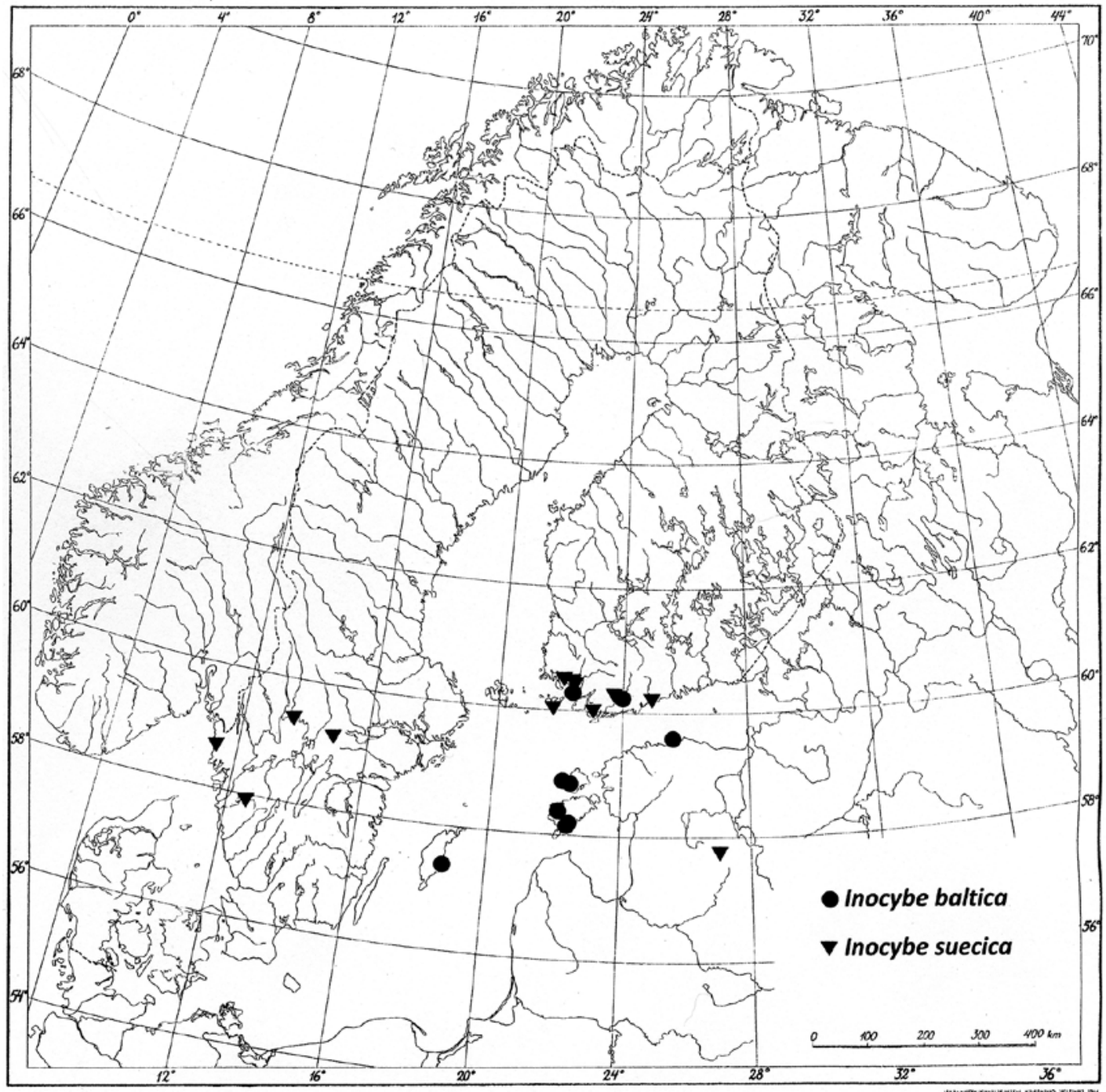

Fig. 9. Distribution of Inocybe baltica and I. suecica in Estonia, Finland and Sweden according to the specimens examined.

Other specimens examined: ESTONIA.Võrumaa. Rõuge, Rõuge cemetery, 4.IX.2010 Liiv* (TU). FINLAND. Varsinais-Suomi. Masku, Lemu, Nyynäinen Nature Reserve, 30.VII.2000 Issakainen \& Vauras 16282 (TUR-A); Lohja, Karjalohja, church park, 31.VII.1998 Vauras $13750 F$ (TUR-A); Parainen, Nauvo, Berghamn, Boskär, Archipelago National Park, 25.VIII.1993 Vauras 8392 (TUR, GB), 2.IX.1998 Vauras,
14327, $14421 F^{*}, 14424 F^{*}$ (TUR-A); Raasepori, Tenhola, Bromarv, Solböle, 11.VIII.1987 Saarenoksa 16387 (H); Turku, Kaerla, 22.VIII.1998 Issakainen \& Vauras 14060F* (TUR-A), Vasaramäki, cemetery, 14.VII.1996 Vauras $11244 F^{*}$ (TUR-A). Uusimaa. Helsinki, Malmi, cemetery, 28.VI.2004 Toivonen 4012 (TUR). SWEDEN. Bohuslän. Tanum, Övre Tun,17.IX.2004 Larsson EL98-04* (GB). Västergötland. Alingsås, Nol- 
hagaparken, 1.IX.2014 Larsson EL95-14 (GB), 16.VII.2016 EL13-16 (GB). Värmland. Karlstad, Ryds kyrkogård, 31.VIII.1990 Jansson* (GB). Närke. Kvistbro, Sixtorp, 9.IX.2008 Larsson EL102-08 (GB), EL105-08*(GB, TUR-A).

Inocybe suecica seems to be associated with broad-leaved trees on rather rich and more calcareous soils. It has been found under Quercus robur, Tilia cordata, Corylus avellana, Betula and Fagus sylvatica, often in older parks and cemeteries, but also at wood margins and in woods. Other Inocybe species found and collected on the same occasions and localities as I. suecica are I. petiginosa (Fr.: Fr.) Gillet, I. rimosa (Bull.: Fr.) P. Kumm., I. langei R. Heim, I. amblyspora Kühner, I. humilis (J. Favre \& E. Horak) Esteve-Rav. \& Vila, I. ochroalba Bruylants and I. geophylla (Fr.: Fr.) P. Kumm.

Inocybe suecica has a rather wide distribution in the hemiboreal zone of Finland, Sweden and Estonia (Fig. 9). There are not very many collections yet, but the fruiting bodies are rather anonymous and small which may contribute to that the species is overlooked. It seems to have a long period of fruiting, from late June to midSeptember, reaching a peak in late August to early September.

\section{Discussion}

Inocybe suecica is characterized by the rather small size of basidiomata, a brown fibrillose pileus, later brownish stipe that is almost totally pruinose, a spermatic smell and quite narrow pleurocystidia with yellowish walls. Further, some of the cauloparacystidia are relatively large. Because of the pruinose stipe we first thought that it belongs to section Splendentes. However, when blasting the ITS and LSU regions separately in GenBank, molecular data suggests it has more affinity to I. sindonia (Fr.) P. Karst. and I. fuscidula Velen. Also in the phylogenetic analyses it falls outside of the Splendentes and the Marginatae clade. So it seems to be more related to species that belong to section Tardae Bon, but without strong support values. Species in Tardae are characterized by having a stipe that is pruinose at apex only. I. sindonia has been placed mostly in Splendentes, as an atypical member with a stipe pruinose more than half-way and with conspicu- ous cortina in young specimens (e.g. Kuyper 1986, Jacobsson \& Larsson 2012). I. fuscidula, on the other hand, has a stipe pruinose about one third to fifth at the apex only, and is a more typical member of Tardae. There are several small species of Inocybe with stipe pruinose at apex only. One of these, having somewhat the same habitus as I. suecica, is I. microspora J.E. Lange, a rather common species in deciduous forests of the hemiboreal zone. It is characterized by having small spores, measuring $6.5-8.5 \times 4-5 \mu \mathrm{m}$.

Acknowledgements: Curator of herbarium TU, Irja Saar, is gratefully acknowledged for arranging a loan. Thanks to Jouni Issakainen, Mika Toivonen, Reima Saarenoksa, Bo Jansson and Vello Liiv for their help with the collections. Bálint Dima, Ditte Bandini and Bernhard Oertel kindly helped us with sequence information. Financial support was received from The Swedish Taxonomy Initiative, ArtDatabanken, SLU, Uppsala, and sequencing through the FinBOL-project funded by the Finnish Cultural Foundation and Kone Foundation. 


\section{References}

Alessio, C.L. \& Rebaudengo, E. 1980: Inocybe. - Iconographica Mycologica Vol. 29, Suppl. 3. Museo Tridentino di Science Naturali, Trento.

Boursier, M.J. \& Kühner, R. 1928: Notes sur le genre Inocybe. I. Les Inocybes goniosporés. - Bull. Soc. Mycol. France 44: 170-189.

Drummond, A.J., Suchard, M.A., Xie, D. \& Rambaut, A. 2012: Bayesian Phylogenetics with BEAUti and the BEAST 1.7. - Molecular Biology and Evolution 29:1969-1973.

Esteve-Raventós, F., Moreno, G., Alvarado P. \& Olariaga, I. 2016: Unraveling the Inocybe praetervisa group trough type studies and ITS data: Inocybe praetervisoides sp. nov. from the Mediterranean region. - Mycologia 108: 123-134.

Esteve-Raventós, F., Moreno, G., Bizio, E. \& Alvarado, P. 2015: Inocybe flavobrunnescens, a new species in section Marginatae. - Mycological Progress 14: 14, DOI: $10.1007 / \mathrm{s} 1557-015-1036-0$.

Favre, J. 1955: Les champignons supérieurs de la zone alpine du Parc National Suisse. - Ergebnisse der wissenschaftlichen Untersuchungen des schweizerischen Nationalparks Band V. 33: 1-212.

Ferrari, E. 2006: Inocybe alpine e subalpine. - Fungi Non Delineati 34-36: 1-457.

Ferrari, E. 2010: Inocybe dai litorali alla zona alpina. Fungi Non Delineati 54-55: 1-216.

Ferrari, E., Bandini, D. \& Boccardo, F. 2014: Inocybe (Fr.) Fr., terzo contributo. - Fungi Non Delineati 73 74: 1-188.

Gardes, M. \& Bruns, T.D. 1993: ITS primers with enhanced specificity for basidiomycetes -application to the identification of mycorrhizas and rusts. - Molecular Ecology 2: 113-118.

Hopple, J.S. Jr. \& Vilgalys, R. 1999: Phylogenetic relationships in the mushroom genus Coprinus and dark spored allies based on sequence data from the nuclear gene coding for the large ribosomal subunit RNA: divergent domains, outgroups, and monophyly. - Molecular Phylogenetics and Evolution 13: 1-19.

Jacobsson, S. \& Larsson, E. 2015: Inocybe granulosa, en ny boreal trådskivling. - Svensk Mykologisk Tidskrift. 36: 46-49.

Katoh, K. \& Standley, D.M. 2013: MAFFT multiple sequence alignment software version 7: improvements in performance and usability. - Molecular Biology and Evolution 30: 772-780.

Kokkonen, K. \& Vauras, J. 2012: Eleven new boreal species of Inocybe with nodulose spores. - Mycological Progress 11: 299-341.

Kuyper, T.W. 1986: A revision of the genus Inocybe in Europe. I. Subgenus Inosperma and the smoothspored species of subgenus Inocybe. - Persoonia Suppl. 3: 1-247.

Kühner, R. 1933: Notes sur le genre Inocybe: 1) Les Inocybes goniosoporés (Fin). - Bull. Soc. Mycol. France 49: 81-121.

Kühner, R. 1955a: Compléments a la "Flore Analytique" V) Inocybe leiosoporés cystidiés. - Bull. Soc. Naturalistes d'Oyonnax 9, Suppl.: 3-95.
Kühner, R. 1955b: Compléments a la "Flore Analytique" V1) Inocybe goniosoporés et Inocybe acystidiés. Bull. Soc. Mycol. France 71: 169-201.

Kühner, R. 1988: Diagnoses de quelques nouveaux Inocybes récoltés en zone alpine de la Vanoise (Alpes françaises). - Documents Mycologiques 19: 1-27.

Kõljalg, U., Nilsson, R.H., Abarenkov, K., Tedersoo, L., Taylor A.F.S., Bahram, M., Bates, S.B., Bruns, T.D., Bengtsson-Palme, J., Callaghan, T.M., Douglas, B., Drenkhan, T., Eberhardt, U., Dueñas, M., Griffith, T.G.W., Hartmann, M., Kirk, P.M., Kohout, P., Larsson, E., Lindahl, B.D., Lücking, R., Martín, R.M.P., Matheny, P.B., Nguen, N.H., Niskanen, T., Oja, J., Peay, K.G., Peintner, U., Peterson, M., Põldmaa, K., Saag, L., Saar, I., Schüssler, A., Scott, J.A., Senés, C., Smith, M.E., Suija, A., Taylor, D.L., Telleria, T., Weiss, M. \& Larsson, K.-H. 2013: Towards a unified paradigm for sequence-based identification of fungi. - Molecular Ecology 22: 5271-5277, DOI: 10.1111/ mec. 12481.

Larsson., E., Vauras, J. \& Cripps, C.L. 2014: Inocybe leiocephala, a species with an intercontinental distribution range - disentangling the I. leiocephala - subbrunnea - catalaunica morphological species complex. - Karstenia 54: 15-39.

Larsson, E. \& Örstadius, L. 2008: Fourteen coprophilous species of Psathyrella identified in the Nordic countries using morphology and nuclear rDNA sequence data. - Mycological Research 112: 1165-185.

Nylander, J.A.A. 2004: MrModeltest v2. - Program distributed by the author.

Ronquist, F. \& Huelsenbeck, J.P. 2003: MrBayes 3, Bayesian phylogenetic inference under mixed models. - Bioinformatics 19:1572-1574.

Ryberg, M., Larsson, E. \& Jacobsson, S. 2010: An evolutionary perspective on morphology and ecological characters in the mushroom family Inocybaceae (Agaricomycotina, Fungi). - Molecular Phylogenetics and Evolution 55: 431-442.

Stang1, J. 1989: Die Gattung Inocybe in Bayern. - Hoppea 46: 5-388.

Swofford, D.L. 2003: PAUP*. Phylogenetic Analysis Using Parsimony (* and Other Methods). Version 4. Sinauer Associates. Sunderland, MA.

Vauras, J. \& Kokkonen, K. 2009: Finnish records on the genus Inocybe. The new species Inocybe saliceticola. - Karstenia 48: 57-67.

Vauras, J. \& Larsson, E. 2011: Inocybe myriadophylla, a new species from Finland and Sweden. - Karstenia 51: 31-36.

Vauras, J. \& Larsson, E. 2015 (2016): Inocybe caprimulgi and I. lacunarum, two new nodulose-spored species from Fennoscandia. - Karstenia 55: 1-18.

White, T.J., Bruns, T., Lee, L. \& Taylor, J.W. 1990: Amplification and direct sequencing of fungal ribosomal RNA genes for phylogenetics. In: Innis, M.A., Gelfand, D.H., Sininski, J.J. \& White, T.J. (eds.): PCR protocols, a guide to methods and applications: 315 322. Academic Press. New York. 
